\title{
Testing of genetically modified novel proteins for allergenicity in food and feed: a toxicological and regulatory challenge
}

\author{
H. M. Bolt · J. G. Hengstler
}

Published online: 22 September 2010

(C) Springer-Verlag 2010

Toxicological aspects of food safety have been a scientific matter for Archives of Toxicology for more than 30 years (Preussmann 1978; Netsch et al. 1980; Miller 1987; Pascal 1992; Bakhiya and Appel 2010). Up to now, topics of carcinogenicity and mutagenicity of food ingredients have been predominating (Preussmann 1978; Bakhiya and Appel 2010). This mostly referred to classical food constituents and additives. However, since the late 1980s new questions arose of toxicological evaluation strategies for so-called "novel food" (Solomons 1987) or for food end-products derived from biotechnology processes (Wilson 1987).

In this context, a matter of recent concern is the allergenicity of genetically modified plant- and microorganism-derived food and feed. Genetically modified food and feed contain quantities of new or existing proteins, which might cause allergies in people and/or animals. For instance, the legislation of the European Union requires that allergenicity of such products should be assessed before these can be placed on the market.

Very recently, the Genetically Modified Organisms (GMO) Panel of the European Food Safety Authority (EFSA) has published an official "Scientific Opinion on strategies for assessing risk of allergenicity of genetically modified plants and microorganisms and derived food and feed" (EFSA 2010). This publication took into consideration a total of 181 comments, received from national assessment bodies, non-governmental organizations, business associations, universities, and individuals during a consultation period. The comments widely addressed the

H. M. Bolt $(\bowtie) \cdot$ J. G. Hengstler

Leibniz Institut für Arbeitsforschung an der TU Dortmund, Leibniz Research Centre for Working Environment and Human Factors (IfADo), Ardeystrasse 67, 44139 Dortmund, Germany e-mail: bolt@ifado.de issue of how to implement the general approach for assessing the allergenicity, as well as how to interpret the results of methods discussed in the Opinion. In vitro and cellbased tests for assessing the allergenicity of newly expressed proteins are covered in Annex 4, and animal models in Annex 6 of the Opinion. On the one hand, Annex 6 stresses that animal models in general are not validated and therefore inconclusive for the assessment of the sensitizing potential of a novel protein. But on the other hand, it acknowledges that such models could provide useful information on mechanisms underlying the induction and development of an allergic reaction, when there are indications of a sensitizing or adjuvant potential of newly expressed proteins. In essence, it appears that hierarchical approaches to allergenicity determination are needed for an integrated assessment.

In the present issue of Archives of Toxicology, Ahuja et al. (2010) provide an up-to-date review of the progress made in this particular field of development of in vivo models, and of possible ways of integration of such models into a science-based hierarchical assessment of novel proteins in food.

By this publication, Archives of Toxicology intends to foster the present discourse between scientists and regulators in this specific field, in order to balance innovation and safety of both food and feed.

\section{References}

Ahuja V, Quatchadze M, Ahuja V, Stelter D, Albrecht A, Stahlmann R (2010) Evaluation of biotechnology derived novel proteins for risk of food allergic potential: advances in the development of animal models and future challenges. Arch Toxicol 84 (this issue)

Bakhiya N, Appel KE (2010) Toxicity and carcinogenicity of furan in human diet. Arch Toxicol 84:563-578 
EFSA Panel on Genetically Modified Organisms [GMO] (2010) Scientific Opinion on the assessment of allergenicity of GM plants and microorganisms and derived food and feed. EFSA $\mathbf{J}$ 8(7):1700 [pp 168]. doi:10.2903/j.efsa.2010.1700. Available online: http://www.efsa.europa.eu

Miller SA (1987) Toxicology and food safety regulations. Arch Toxicol 60:212-216

Netsch W, Busch A, Hornawsky G, Laue W, Rummler HJ, Strey A (1980) Toxicological tests on the safety of fermosin for pigs, a novel microbial feed from petroleum distillate. Arch Toxicol Suppl 4:439-442
Pascal G (1992) Risk assessment: governmental aspects. Arch Toxicol Suppl 15:75-82

Preussmann R (1978) Toxicological aspects of food safety-carcinogenicity and mutagenicity. Arch Toxicol Suppl 1:69-84

Solomons GL (1987) Myco-protein: safety evaluation of a novel food. Arch Toxicol Suppl 11:191-193

Wilson AB (1987) The toxicology of end products from biotechnology processes. Arch Toxicol Suppl 11:194-199 